\section{Cientific Paper}

\section{Abstract}

Cassava is the fourth culture in the world's most important food productions and is the first in the tropical region. The average yield among cassava producers in Tocantins is of only 15 tons per hectare. Therefore, there is a dearth of information on the cassava, which makes necessary the performance of studies and evaluation of crop as for its characteristics. The aim of this study was to assess the performance of two cassava varieties (sweet and bitter), with different spacings. The experimental design was a factorial

\title{
Performance of two cassava varieties submitted to different spacings, grown in the cerrado region
}

Estela Guisi Bagio Zanetti Eliane Maria Glória Cardoso Daisy Parente Dourado Evandro Reina ${ }^{4}$

Cid Tacaoca Muraishi ${ }^{5}$ scheme $2 \times 3 \times 4$, with two varieties, IAC 12 (bitter) and Cocoa (sweet) and three spacings $(0.90 \times 0.50 \mathrm{~m}),(0.90 \times 0.70 \mathrm{~m})$, $(0.90 \times 0.90 \mathrm{~m})$ with four replications. The evaluated variables were: a) Plant height (AP), b) Root Weight (RW), c) Starch content (SC); d) Dry Matter of Root (DM); e) Determination of $\mathrm{pH}$ of the cassava mass. The values obtained were subjected to analysis of variance and the averages were compared by Tukey test at $5 \%$ of probability. The variety Cocoa grown under the three spacings was the one which better stood as for the plant height. Insofar as the spacing was increased, the production of dry mass of the roots decreased. The values of $\mathrm{pH}$ and starch content of the roots were not influenced by spacing and varieties. The spacing which better adjusted in function of the cassava roots productivity was the one of $(0.9$ $x 0.7 \mathrm{~m}$ ), which is a viable option to the producer, which can provide lower cost of cuttings per planted area and yield for the cultivation conditions in Tocantins.

Keywords: Manihote sculenta Crantz; Variety IAC 12; cocoa variety.

\section{Desempenho de duas variedades de mandioca submetidas a diferentes espaçamentos, cultivadas na região dos cerrados}

\section{Resumo}

A mandioca é a quarta cultura na produção de alimentos mais importante do mundo e a principal na região tropical. A produtividade média entre os produtores de mandioca no Tocantins é de apenas 15 toneladas por hectare. Desta forma, existe uma carência de informações sobre a cultura da mandioca, o que torna necessário a realização de estudos e avaliação da cultura quanto às suas características. O objetivo deste trabalho foi avaliar o desempenho de duas variedades de mandioca (brava e mansa), em função de diferentes espaçamentos. O delineamento experimental utilizado foi em esquema fatorial $2 \times 3 \times 4$, sendo duas variedades, IAC 12 (brava) e a Cacau (mansa) e três espaçamentos $(0,90 \times 0,50 \mathrm{~m}),(0,90 \times 0,70 \mathrm{~m})$, $(0,90 \times 0,90 \mathrm{~m})$, com quatro repetições. As variáveis avaliadas foram: a) Altura de Planta (AP); b) Peso da Raiz (PR); c) Teor de Amido (TA); d) Massa Seca da Raiz (MS); e) Determinação do pH da Massa da Mandioca. Os valores obtidos foram submetidos à análise de variância e as médias comparadas pelo teste de Tukey a 5\% de probabilidade. A variedade Cacau cultivada sob os três espaçamentos foi a que melhor se destacou quanto a característica altura de plantas. Na medida em que se aumentou os espaçamentos, a produção de massa seca de raízes diminuiu. Os valores de $\mathrm{pH}$ e teor de amido das raízes não foram influenciados pelos espaçamentos e variedades. O espaçamento que melhor se ajustou em função da produtividade de raízes de mandioca foi o de $(0,9 \times 0,7 \mathrm{~m})$, sendo esta uma opção viável ao produtor que proporcionará menor gasto de manivas por área plantada e rentabilidade para as condições de cultivo do estado do Tocantins.

Palavras-chave: Manihote sculenta Crantz; Variedade IAC 12; Variedade Cacau.

\footnotetext{
Received at: 18/08/2013

Accepted for publication at: 11/02/2014

1 Masters degree student, Federal Institute of Education, Science and Technology Fluminense. E-mail:estela.zanetti81@gmail.com.

Agronomy Engineer - Catholic University of Tocantins, CEP: 77006-100 Palmas-TO. E-mail: daisyagro@gmail.com

3 Undergraduate in the Agronomy Course at the Catholic University of Tocantins, CEP: 77006-100 Palmas-TO. E-mail: daisyagro@gmai com

4 Agronomy Engineer, M. Sc., Professor in the Agronomy Course at the Catholic University of Tocantins, CEP: 77006-100 Palmas-TO. E-mail: evandro.reina@catolica-to.edu.

5 Agronomy Engineer, D. Sc., Professor in the Agronomy Course at the Catholic University of Tocantins, CEP: 77006-100 Palmas-TO. E-mail:cid@catolica-to.edu.br. Author for correspondence.
}

Applied Research \& Agrotecnology $v 7$ n1 jan/apr. (2014)

Print-ISSN 1983-6325 (On line) e-ISSN 1984-7548 


\section{Rendimiento de dos variedades de yuca en diferentes espaciamientos, en la región del cerrado}

\section{Resumen}

La yuca es el cuarto cultivo más importante del mundo en la producción de alimentos y la en la principal en la región tropical. El rendimiento promedio entre los productores de yuca en Tocantins está a sólo 15 toneladas por hectárea. De esta manera, hay una falta de información sobre la cultura de yuca, lo que hace necesaria la realización de estudios y la evaluación de la cultura y sus características. El propósito de este estudio fue evaluar el rendimiento de dos variedades de yuca "brava y mansa" (silvestre y domesticado), en función de diferentes espaciamientos. El diseño experimental fue un factorial $2 \times 3 \times 4$, con dos variedades, IAC 12 (sylvestre) y Cacau (domesticado) y tres espaciamientos $(0,90 \times 0,50 \mathrm{~m}),(0,90$ x 0,70 m) y (0,90 x 0,90 m), con cuatro replicaciones. Se evaluó las variables: a) Altura de la planta (AP); b) Peso de la raíz (PR); c) Contenido de almidón (TA); d) masas seca de raíz (MS); e) Determinación del pH de la masa de yuca. Los datos fueron sometidos a análisis de varianza y se comparó las medias mediante la prueba de Tukey al $5 \%$ de probabilidad. La variedad Cacau cultivado bajo los tres espaciamientos fue el que se ha destacado cuanto la característica altura de plantas. En la medida en que se aumento el espaciamiento, la masa seca de las raíces disminuyó. Los valores de pH y del contenido de almidón de las raíces no fueron influenciados por el espaciamiento y por las variedades. El mejor ajuste de espaciamiento para la productividad de raíces de la yuca fue $0,9 \times 0,7 \mathrm{~m}$, siendo ésta una opción viable para el productor, pues puede proporcionar bajo costo de esquejes por área plantado y rentabilidad en las condiciones de cultivo del estado de Tocantins.

Palabras clave: Manihote sculenta Crantz; variedad IAC 12; variedad Cacau.

\section{Introduction}

Cassava is the fourth culture in the world's most important food productions and is the first in the tropical region. The root of the plant and its sub products are consumed by more than 800 millions of people (FAO, 2012). Tuberous plants, among which stand out the cassava (Manihot esculenta Crantz) are cultivated worldwide, mainly in countries that lie between $30^{\circ}$ north and south of latitude, in relation to the Equator.

According to the Brazilian Institute of Geography and Statistics, IBGE (2012), the national production of cassava reached 25.4 millions of tons in 2011 , a growth of $3.7 \%$ in relation to the previous year. The socioeconomic importance of the cassava crop transcends the food issue, especially for the poorest populations, finding new and promising ways of industrial use as function of the versatility of its products and derivatives. Such processes of industrialization demand from the producer the immediate adoption of new production systems, with adequate management of soils and mechanized planting, dimensioned spacings in order to facilitate harvesting operations, adapted and productive varieties, streamlining of time and optimization of costs of harvest (SCALON FILHO et al., 2005). The cassava has many current and potential uses, classified according the root type in two great categories: sweet cassava and cassava for the industry (SOUZA et al., 2006).

In this sense, the management of population densities promotes major changes in the plants development, being that the optimal adjustment, besides of little studied, is not used by the producers who are unaware of their advantages. Plants cultivated in a more condensed form, although may provide greater yields, present smaller roots, thus compromising the commercial quality. When submitted to smaller densities of planting, apart the roots develop faster, it present greater individual development, providing greater commercial quality, such as roots uniformity (AGUIAR, 2003).

The best spacings and plants populations for the cassava crop are influenced by differences that each cultivar presents in the architecture of shoots and in the format and distribution of tuberous roots. Above the optimum population, which provides maximum productivity, there is decrease of size of the roots.(COCK et al., 1977; TAKAHASHI, 1998).

To ZADA and BECALLI (1982), in fewer populations, there is a greater photo-assimilated harnessing, due these starting to filter by the pores faster, from leaves to roots during plant growth. Several planted cultivars with density of 2.500 to 40.000 plants ha-1 and harvested at 12 months, presented roots yield increase in larger populations, being a good characteristic for the industry. However, 


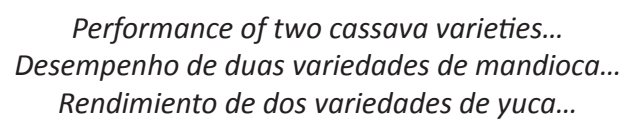

for consumption, where are desirable big roots, the best population was of 10.000 plants ha-1 for cultivars with upright shoots and 5.000 plants ha-1, for branched (TORO and ATLEE, 1984).

The spacing in cassava cultivation depends on the soil fertility, size of variety, objective of production (roots or branches), crop traits and type of harvest (manual or mechanized).

Due to the wide variability of soil, weather and used cultivars in Brazil, it becomes difficult to establish a standard spacing for the crop. The determination of spacing depends on soil fertility and the regions' climate, type of used cultivar and objective of the crop. In the country predominates planting in single rows, being that lately for certain regions it is recommended the use of double rows (SILVA and ROEL, 2001).

The crop spacing occurs according to type of varieties, soil fertility and cultivation system. The varieties can present upright or branched shoots and long of short roots. Varieties of upright shoots can be planted in smaller spacings, whereas the branched are used for planting in wider spacings. In more fertile terrains plants can be more spaced (ALVES, 2009).

The average yield among cassava producers in Tocantins is only 15 tons per hectare. The backyard and subsistence cultivation; the shortage of capital and lack of organization of producers; instability of market; and the difficulties in the system are some factors that have contributed for this low production (AZEVEDO, 2002).

In this sense, there is a scarcity of information on the cassava crop, which turns to be necessary, the performance of studies and assessment of the crop as for its characteristics. The aim of this study was evaluate the performance of two cassava varieties (bitter and sweet), according to different spacings.

\section{Material and Methods}

The study was conducted at the Experimental Campus of the Faculdade Católica do Tocantins FACTO, Agricultural and Environmental Sciences Campus, located in the municipality of Palmas TO. The experimental area presents geographical coordinates of $48^{\circ} 17^{\prime} 31.77^{\prime \prime} \mathrm{W}$ and $10^{\circ} 17^{\prime} 2.80^{\prime \prime} \mathrm{S}$ and altitude of $230 \mathrm{~m}$.

According to the international classification of Köppen, the regions' weather is of the type $\mathrm{C} 2 \mathrm{wA}^{\prime} \mathrm{a}^{\prime}$ Wet sub-humid climate with a small water deficiency, in winter, potential evapotranspiration with annual average of $1.500 \mathrm{~mm}$, distributing in summer around $420 \mathrm{~mm}$ during three consecutive months with higher temperatures, presenting temperature and annual rainfall of $27.5^{\circ} \mathrm{C}$ and $1600 \mathrm{~mm}$, respectively, and average relative humidity of $80 \%$ (INMET, 2012).

The previous soil classification used in the area was determined by combining the Latossolo Vermelho-Amarelo ${ }^{1}$ concessionaire or not, medium and clayey texture, soft wavy relief + concretionary indiscriminate soils $\mathrm{Tb}$ indiscriminate texture, soft wavy relief and wavy, both dystrophic (EMBRAPA, 1999).

The experiment was carried out in the 2011/12 season. The used experimental design was in a factorial scheme $2 \times 3 \times 4$, being two varieties, IAC 12 (bitter) and the Cocoa (sweet) and three spacings $(0.90 \times 0.50 \mathrm{~m}),(0.90 \times 0.70 \mathrm{~m}),(0.90 \times 0.90 \mathrm{~m})$, with four repetitions. The stalks were cut with $0.13 \mathrm{~m}$ of length, which were put horizontally into the holes at a depth of $0.10 \mathrm{~m}$.

Prior to the experiment installment, was performed the chemical analysis of the soil, which presented the following characteristics: $\mathrm{pH}$ (4.6); $\mathrm{P}_{2} \mathrm{O}_{5}\left(6.0 \mathrm{mg} \mathrm{dm}{ }^{-3}\right) ; \mathrm{K}_{2} \mathrm{O}\left(0.8 \mathrm{mg} \mathrm{dm}{ }^{-3}\right) ; \mathrm{Ca}^{2+}(1.8 \mathrm{mg}$ $\left.\mathrm{dm}^{-3}\right) ; \mathrm{Mg}^{2+}\left(1.0 \mathrm{cmol}_{\mathrm{c}} \mathrm{dm}^{-3}\right) ; \mathrm{Al}^{3+}\left(0 \mathrm{cmol}_{\mathrm{c}} \mathrm{dm}^{-3}\right) ; \mathrm{H}+\mathrm{Al}$ $\left(2.2 \mathrm{~g} \mathrm{~kg}^{-1}\right)$; $\mathrm{MO}\left(1.8 \mathrm{~g} \mathrm{~kg}^{-1}\right)$; Sand (67\%); Silt (7\%) and Clay $(26 \%)$.

Soil preparation of the experimental area was carried out conventionally with heavy disking, disc harrows for obtaining optimal conditions for the experiment installation.

The crop conduction demanded manual hoeing during the initial stage of vegetative development, for the control of weeds and sprouting of grasses. Fertilizations were performed according recommendation of the $5^{\text {th }}$ approach of the Comissão de Fertilidade de Solos de Goiás² (1988).

The first cover fertilization was applied 50 days after the planting. The second was performed at the $90^{\text {th }}$ day after the emergence.

Weed control was carried out through manual hoeing during the crop cycle. In the experimental area, the water supply in the crop cycle occurred when there was no rainfall, by means of an irrigation system by aspersion $\left(6 \mathrm{~mm}\left(\mathrm{H}_{2} \mathrm{O}\right)^{-1}\right.$ day $\left.^{-1}\right)$.

The assessments of studied characters were done at the $8^{\text {th }}$ month after the planting, with manual harvest of the tuberous roots. Next, the roots were

1 Brazilian soil classification.

2 Brazilian institution. 
weighed, and a part of them were selected and separated for analysis in the Laboratory of the Faculdade Católica Tocantins.

The evaluated characteristics were: a) Plant Height (AP), in which were measured plants in each plot in centimeters, with a graduated rule, from the soil to the base of insertion of the last leaf; b) Root Weight (RW), with average value expressed in $\mathrm{kg} \mathrm{ha}^{-1}$ and obtained by weighing the roots produced by the useful plants of the plot, using analytical balance ( 0.1 g). The root weight was produced in a unity of area of 24 plots and then extrapolated to $\mathrm{kg} \mathrm{ha}^{-1}$; c) Starch Content (SC) of each plot, where was retrieved a sample of $5.0 \mathrm{~kg}$ of roots for the determination of the average percentage of starch, using the hydrostatic balance method (GROSSMAN and FREITAS, 1950); d) Dry mass of the root (DM), being the cassava moisture content determined gravimetrically, in a greenhouse at $105^{\circ} \mathrm{C}$, until constant weight, according the methodology proposed by FRANCO et al. (2002); e) Determination of $\mathrm{pH}$ of the Cassava Mass, this analysis has as base the methodology described by the Adolfo Lutz Institute, whereby was taken the electronic reading of $\mathrm{pH}$ from a solution of grated cassava and water (FRANCO et al., 2002).

The obtained values were submitted to variance analysis and the averages were compared through the Tukey test, considering $5 \%$ of probability for both tests.

\section{Results and Discussions}

The values obtained in the variance analysis revealed significant differences for the data of varieties and spacings of cassava crop (Table 1). It was verified that there was significant effect for the different varieties as well as for interaction between variety $x$ spacing for the variables plant height $(\mathrm{AP})$, root weight (RW), dry mass (DM) and starch content (SC).

It is observed that there was significant difference between treatments (Table 2), regarding the variable plant height $(\mathrm{AP})$, the variety Cocoa presented the highest averages $(1.75 \mathrm{~m})$, significantly differing from the IAC 12 (1.40). This variation, according to RIMOLDI et al. (2006), occurred due to environment influence and to the genotypic components expressed in the studied varieties.

There was no significant difference between the studied varieties for $\mathrm{pH}$ values of cassava mass. Both presented average $\mathrm{pH}$ of 6.4. According to SEBRAE (2009) data, it is not possible to establish any relation between spacing and variety for the $\mathrm{pH}$ of cassava mass, because where $\mathrm{pH}$ is directly linked

Table 1. Summary of variance analysis of the following characteristics: plant height (AP), root weight (RW), dry mass (DM), starch content (SC), $\mathrm{pH}$ of the cassava mass, in function of two varieties and three spacings. Palmas - TO, 2012.

\begin{tabular}{|c|c|c|c|c|c|}
\hline \multirow{2}{*}{ Variation Coefficient } & AP & RW & DM & SC & $\mathrm{pH}$ \\
\hline & $\mathbf{m}$ & $\mathrm{Kg} \mathrm{ha}^{-1}$ & $\%$ & $\mathrm{Kg} \mathrm{ha}^{-1}$ & \\
\hline Variety (V) & $84.55 * *$ & $36.15^{* *}$ & $32.31 * *$ & $10.69 * *$ & $0.34 \mathrm{~ns}$ \\
\hline Spacing $(\mathrm{E})$ & $3.41 \mathrm{~ns}$ & $83.35 * *$ & $59.91 * *$ & $89.16 * *$ & $1.51 \mathrm{~ns}$ \\
\hline $\mathrm{V} \times S$ & $1.04 \mathrm{~ns}$ & $29.40 * *$ & $16.89 * *$ & $25.36 * *$ & $0.23 \mathrm{~ns}$ \\
\hline $\mathrm{VC} \%$ & 5.88 & 8.18 & 10.16 & 8.33 & 2.75 \\
\hline
\end{tabular}

** Significant at the level of $1 \%, *$ significant at the level of $5 \%, n$ s non significant.

Table 2. Averages of the characteristics of plant height (AP) and determination of $\mathrm{pH}$ of the cassava mass, assessed in two varieties and three spacings. Palmas - TO, 2012.

\begin{tabular}{cccccc}
\hline \multirow{2}{*}{ Varieties } & AP & RW & DM & SC & pH \\
\cline { 2 - 6 } & m & Kg ha $^{-1}$ & Kg ha $^{-1}$ & Kg ha $^{-1}$ & \\
\hline IAC 12 & $1.40 \mathrm{~b}$ & - & - & - & -4.4 \\
Cocoa & $1.75 \mathrm{a}$ & - & - & - & $6.4 \mathrm{a}$ \\
\hline
\end{tabular}

Averages followed by the same letter in the columns do not differ, by the Tukey test, at $5 \%$ of probability. 


\section{Performance of two cassava varieties... \\ Desempenho de duas variedades de mandioca.. \\ Rendimiento de dos variedades de yuca...}

to acid content, is in the cassava starch, the starchy product extracted from cassava, which according to its content can be modified into food, where the sweet cassava starch presents $\mathrm{pH}$ around 6.5, while the bitter cassava starch has $\mathrm{pH}$ around 4.5.

Assessing the data presented in Table 3, which shows the interaction between varieties $x$ spacings, it is noteworthy that for the IAC 12 variety, the spacing $(0.9 \times 0.7)$ stood out from the other spacings, and provided an average production of $32,842.32 \mathrm{~kg} \mathrm{ha}^{-1}$.

In the spacings $(0.9 \times 0.5 \mathrm{~m})$ and $(0.9 \times 0.9 \mathrm{~m})$ the averages did not differ as for the production, being that the first spacing had $22.775 .36 \mathrm{~kg} \mathrm{ha}^{-1}$ and the second $20,186.55 \mathrm{~kg} \mathrm{ha}^{-1}$. The yield averages were similar to those found by VIDIGAL FILHO et al. (2000), who assessed the same IAC 12 variety in the northwest region of Paraná, during the seasons 1994/95, 1995/96 and 1996/97.

For the Cocoa variety, there were significant differences in the spacing $(0.9 \times 0.9 \mathrm{~m})$, which presented a lower production of $19,288.22 \mathrm{~kg} \mathrm{ha}^{-1}$, differing from the other spacings, that presented productions of $38,442.54 \mathrm{~kg} \mathrm{ha}^{-1}$ and $35.001 .40 \mathrm{~kg} \mathrm{ha}^{-1}$. DINIZ et al. (2009), analyzing the varieties of sweet cassava in Guaratinga, Bahia, for the spacings $(0.9 x$ $0.5 \mathrm{~m})$ and $(0.9 \times 0.7 \mathrm{~m})$, reported in his study that the Cocoa variety achieved a production of $32,800.00$ $\mathrm{kg} \mathrm{ha}^{-1}$.

Therefore, the production found in this study is within the expected for the variety. Many authors showed increases in production with smaller planting spaces (COCK et al., 1977; MONDARDO, et al., 1995, NORMANHA and PEREIRA, 1950). Other authors also show decreases in productions of roots per unit area, thus increasing the spacings (FURTADO et al., 1980; MONDARDO et al., 1995; SAMPAIO and CONCEIÇÃO, 1975).

On comparing the varieties, it is observed that the spacings presented significant difference when having $(0.9 \times 0.5 \mathrm{~m})$, where the Cocoa variety presented the best productivity results with $38,442.54$ $\mathrm{kg} \mathrm{ha}^{-1}$. Nevertheless, different responses were found depending on the variations between planting spacings, according to the characteristics of each variety (COCK et al., 1979). As stated by the author, smaller densities are recommended for soils of good fertility, while higher densities provide the best yields in soils of low fertility.

In Table 4, one realizes that when comparing the varieties depending on spacings, is observed that there is no significant difference for the factor spacing $(0.9 \times 0.9 \mathrm{~m})$, however, when compared, it can be noted that the Cocoa variety presented the highest contents of dry mass, $14,236.30 \mathrm{~kg} \mathrm{ha}^{-1}$ in the spacing $(0.9 \times 0.5 \mathrm{~m})$ and $13,821.18 \mathrm{~kg} \mathrm{ha}^{-1}$ in the spacing $(0.9 \times 0.7 \mathrm{~m})$.

Moreover, it is observed that the spacing ( 0.9 $x 0.7 \mathrm{~m}$ ) presented the best results for the IAC 12 variety with $12,080.78 \mathrm{~kg} \mathrm{ha}^{-1}$, similar results were found by Rimoldi et al. (2003), when assessing the IAC 12 variety in the municipalities of Maringá and Rolândia in the Paraná state. As for the Cocoa variety,

Table 3. Unfolding of the interaction varieties $x$ spacings, significant for the roots weight (RW) of the cassava crop. Palmas - TO, 2012.

\begin{tabular}{cccc}
\hline \multirow{2}{*}{ Varieties } & \multicolumn{3}{c}{ Spacings } \\
\cline { 2 - 4 } & $\mathbf{0 . 9 \times 0 . 5 ~ \mathbf { ~ }}$ & $\mathbf{0 . 9} \mathbf{0 . 7} \mathbf{~ m}$ & $\mathbf{0 . 9 \times 0 . 9 ~ \mathbf { ~ }}$ \\
\hline IAC12 & $22.775 .36 \mathrm{bB}$ & $32.842 .32 \mathrm{aA}$ & $20.186 .55 \mathrm{aB}$ \\
Cocoa & $38.442 .54 \mathrm{aA}$ & $35.001 .40 \mathrm{aA}$ & $19.288 .22 \mathrm{aB}$ \\
\hline
\end{tabular}

Averages followed by the same letter, lowercase in column and uppercase in the line do not statistically differ, by the Tukey test, at the level of $5 \%$ de probability.

Table 4. Unfolding of the interaction varieties x spacings, significant for dry mass (DM) of the cassava roots. Palmas - TO, 2012.

\begin{tabular}{cccc}
\hline \multirow{2}{*}{ Varieties } & \multicolumn{3}{c}{ Spacings } \\
\cline { 2 - 4 } & $\mathbf{0 . 9} \times \mathbf{0 . 5} \mathbf{~ m}$ & $\mathbf{0 . 9} \times \mathbf{0 . 7} \mathbf{~}$ & $\mathbf{0 . 9} \times \mathbf{0 . 9} \mathbf{~ m}$ \\
\hline IAC 12 & $8.355 .70 \mathrm{bB}$ & $12.080 .78 \mathrm{bA}$ & $7.367 .77 \mathrm{aB}$ \\
Cocoa & $14.236 .30 \mathrm{aA}$ & $13.821 .18 \mathrm{aA}$ & $7.176 .98 \mathrm{aB}$ \\
\hline
\end{tabular}

Averages followed by the same letter, lowercase in column and uppercase in the line do not statistically differ, by the Tukey test, at the level of $5 \%$ de probability.

Applied Research \& Agrotecnology v7 n1 jan/apr. (2014)

Print-ISSN 1983-6325 (On line) e-ISSN 1984-7548 
the greater spacing $(0.9 \times 0.9 \mathrm{~m})$, was the one which statistically differed, presenting the lowest contents of dry mass, $7 \cdot 176,98 \mathrm{~kg} \mathrm{ha}^{-1}$. According to the authors Cock et al. (1977) and Hunt et al. (1977), the dry mass content of tuberous roots tends to decrease with the increase of planting densities.

The dry mass content is the characteristic which determines the greater or lesser industrial yield of roots, once it is directly related to several products derived from cassava. It is desirable that the varieties responsible by the greatest productions of tuberous roots are also those that have the highest dry mass contents, thus maximizing the yield of the final product per unit of cultivated area (SARMENTO, 1997).

Analyzing the starch content characteristic, according to Table 5, it can be observed that the largest spacings did not provide significant difference, as for the varieties, there was difference only for the smallest spacing, where the Cocoa variety provided the highest starch content, 3,754.24 kg ha $^{-1}$. When comparing spacings, the IAC 12 variety presented the highest starch content in the spacing $0.9 \times 0.7 \mathrm{~m}$, being around of 3,555.45 $\mathrm{kg} \mathrm{ha}^{-1}$.

Studies done by Otsubo et al. (2009) and Vidigal Filho et al. (2000), confirm the genetic potential of starch production of the IAC 12 cultivar, as was observed in this study. The starch content is a characteristic that is usually used by the industry as evaluation criteria and payment for producers.

Nevertheless, for the Cocoa variety, the spacings $(0.9 \times 0.5 \mathrm{~m})$ and $(0.9 \times 0.7 \mathrm{~m})$ did not statistically differ, now the spacing $(0.9 \times 0.9 \mathrm{~m})$ provided the smallest starch content, $1,846.90 \mathrm{~kg} \mathrm{ha}^{-1}$. The results of this evaluation were similar to those found by Diniz et al. (2009), who assessed the sweet cassava variety with small farmers of Guaratinga, BA.

Table 5. Unfolding of the interaction varieties $x$ spacings, significant for starch content (SC) of the cassava roots. Palmas - TO, 2012.

\begin{tabular}{cccc}
\hline \multirow{2}{*}{ Varieties } & \multicolumn{3}{c}{ Spacings } \\
\cline { 2 - 4 } & $\mathbf{0 . 9 \times 0 . 5 ~ \mathbf { ~ }}$ & $\mathbf{0 . 9} \mathbf{0 . 7} \mathbf{~ m}$ & $\mathbf{0 . 9} \mathbf{0 . 9} \mathbf{~ m}$ \\
\hline IAC 12 & $2.459 .21 \mathrm{bB}$ & $3.555 .45 \mathrm{aA}$ & $2.107 .50 \mathrm{aB}$ \\
Cocoa & $3.754 .24 \mathrm{aA}$ & $3.477 .49 \mathrm{aA}$ & $1.846 .90 \mathrm{aB}$ \\
\hline
\end{tabular}

Averages followed by the same letter, lowercase in column and uppercase in the line do not statistically differ, by the Tukey test, at the level of $5 \%$ de probability.

\section{Conclusions}

The Cocoa variety cultivated on the three spacings was the one which stood out as for the plant height characteristic.

As the spacings are increased, the dry mass production of roots decreases.
The $\mathrm{pH}$ values and starch content of roots were not influenced by spacings and varieties.

The spacing which better adjusted as function of cassava roots yield was the $0.9 \times 0.7 \mathrm{~m}$, being this is a viable option to the producer, which will provide smaller expanse of cuttings per planted area and yield for the cultivation conditions of the Tocantins state.

\section{References}

AGUIAR E. B. Produção e Qualidade de Raízes de Mandioca de Mesa (Manihot esculenta Crantz) em Diferentes Densidades Populacionais e Épocas de Colheita. Campinas Estado de São Paulo Julho - 2003.

ALVES, M. C.S. Recomendações Técnicas para o Cultivo da Mandioca. VI Circuito de Tecnologias Adaptadas para a Agricultura Familiar. Natal, RN 2009.

AZEVEDO, R. Empresa Brasileira de Pesquisa Agropecuária. Embrapa Cerrados. Dia de Campo mostra como melhorar a produção de mandioca. Outubro 2002. Disponível em: <http:/ /www.embrapa.br/imprensa/ noticias/2002/outubro/bn.2004-125.5427758478 > Acesso em 20 ago. de 2012. 


\footnotetext{
Performance of two cassava varieties...

Desempenho de duas variedades de mandioca...

Rendimiento de dos variedades de yuca...
}

COCK, J. H.; FRANKLIN, D.; SANDOVAL, G.; JURI, P. The ideal cassava planting for maximum yield. Crop Science, Madison, v. 19, p.271-279, 1979.

COCK, J. H.; WHOLEY, D.; CASAS O. G. de las. Effect of spacing on cassava (Manihote sculenta). Experimental Agriculture, Great Britain, v. 13, p. 289-299, 1977.

COMISSÃO DE FERTILIDADE DE SOLOS DE GOIÁS. Recomendações de corretivos e fertilizantes para Goias: 5a aproximação. Goiania: UFG/EMGOPA, 1988. 101 p. (Informativo Técnico, 1).

DINIZ, M. S.; OLIVEIRA, A. M. G.; PEREIRA, N. L.; OLIVEIRA J, L. Avaliação de Variedades de Mandioca Mansa com Agricultores Familiares.In: XIII Congresso Brasileiro de Mandioca. 2009. GUARATINGA, BA.

EMBRAPA - Empresa Brasileira de Pesquisa Agropecuária. Sistema brasileiro de classificação de solo. Rio de Janeiro: CNPS. 1999. 412p.

FAO. Food and agriculture organization of the united nations. Disponível em: <www.faostat.fao.org/ site/340/default.aspx > Acesso em: 15 ago. de 2012.

FRANCO, CML, et.al. In: Propriedades gerais do amido. Metodologias de análise de amido. São Paulo: Fundação Cargill, 2002. v. 1, p. 185-203.

FURTADO, M. J.; SILVA, A. A. da.;SANTOS J. A. C.; OLIVEIRA, D. de. Espaçamento para mandioca (Manihot Esculenta Crantz), no norte do Espírito Santo. Indicação EMCAPA, Cariacica, v. 2, n. 3, p. 1-5, 1980.

HUNT, L. A.; WHOLEY, D. W.; COCK, J. H. Growth physiology of cassava. Field Crop abstracts, Farnham Royal, v. 30, n. 2, 77-91, 1977.

IBGE. Instituto Brasileiro de Geografia e Estatística. Produção Agrícola Municipal 2011. Comunicação Social. Disponível em: <http://www.ibge.gov.br/home/presidencia/noticias/noticia_visualiza.php?id_ noticia $=2246 \& i d \_$pagina $=1 \&$ titulo=PAM-2011:-valor-da-producao-agricola-cresce-27,1\%-em-relacao-a-2010> Acesso dia 26 de outubro de 2012.

INSTITUTO NACIONAL DE METEOROLOGIA -INMET. Dados meteorológicos. Disponível em: <http:/ / www.inmet.gov.br/>. Acesso dia 15 de agosto de 2012.

MONDARDO, E.; DIETRICH, R. C.; LAVINA, M. L. Efeito da densidade de plantio da mandioca na produção de raízes em solo Araranguá. Agropecuária Catarinense, Florianópolis, v. 8, n. 4, 1995.

NORMANHA, E. S.; PEREIRA A. S. Aspectos agronômicos da cultura da mandioca. Bragantia, Campinas, v. 10, n. 7, p. 179-202. 1950.

OTSUBO, A. A.; BRITO, O. R.; MERCANTE, F. M.; NAKASE, V. H.; GONÇALVES, M. A.; TELLES T. S. Desempenho de cultivares elites de mandioca industrial em área de cerrado do Mato Grosso do Sul. Semina: Ciências Agrárias, Londrina, v. 30, suplemento 1, p. 1155-1162, 2009.

RIMOLDI, F.; VIDIGAL FILHO, P.S; VIDIGAL, M.C.G.; CLEMENTE, E. PEQUENO, M.G.; MIRANDA, L.; KVITSCHAL, M. V. Produtividade, composição química e tempo de cozimento de cultivares de mandioca de mesa coletadas no Estado do Paraná. Acta Scientarum Agronomy. Maringá, v.28, n.1, p.63-69, jan/mar., 2006.

RIMOLDI, F.; VIDIGAL FILHO. P.S., SCAPIM, C. A.; VIDIGAL, E.; GONÇALVES, M. C.; Avaliação de cultivares de mandioca nos municípios de Maringá e de Rolândia no Estado do Paraná. Acta Scientiarum. Agronomy, Maringá, v. 25, no. 2, p. 459-465, 2003.

SAMPAIO, C. V.; CONCEIÇÃO, A. J. da. Espaçamento na cultura da mandioca (Manihote sculenta Crantz). In: Projeto mandioca. Cruz das almas: Universidade Federal da Bahia; Branscan Nordeste, 1975 p. 99-105. (série Pesquisa ano 2, n. 1).

SARMENTO, B.S. Caracterização da fécula de mandioca (Manihote sculenta, Crantz) no período de colheita de cultivares de uso industrial. 1997. 162 p. Tese (Doutorado) - Faculdade de Ciências Farmacêuticas, Universidade de São Paulo, São Paulo.

SCALON FILHO, H.; SOBRINHO, T.A.; SOUZA, C.M.A. de. Desempenho de dois equipamentos na colheita semimecanizada da cultura da mandioca. Engenharia Agrícola, Jaboticabal - SP, v.25, n.2, p.557-564, 2005. 
SEBRAE. Serviço de Apoio às Micro e Pequenas Empresas da Bahia. Mandiocultura:Derivados da Mandioca. Salvador. Bahia. 2009.

SILVA, M. J.; ROEL, A. R. Cultivo da Mandioca e Derivados Mato Grosso do Sul. Gráfica: GrafNews 2001. SOUZA, L. S., FARIAS., R. N. Aspectos socioeconômicos e agronômicos da mandioca. Cruz das Almas BA. Embrapa Mandiocae Fruticultura Tropical, 817 p., 2006.

TAKAHASHI, M.; GUERINI V. L. Espaçamento para a Cultura da Mandioca Instituto Agronômico do Paraná (IAPAR). Palotina, PR.Revised: April 04, 1998.

TORO, J.C; ATLLE, C.B. Práticas agronômicas para a produção de mandioca. revisão bibliográfica. In: EMBRAPA. Práticas culturais da mandioca: anais do seminário realizado em Salvador, Brasil. Brasília, EMBRAPA-DDT. 245 p.1984.

VIDIGAL FILHO, P. S.; PEQUENO, M. G.; SCAPIM, C. A.; VIDIGAL, M. C. G.; MAIA, R. R.; SAGRILO, E.; SIMON, G. A.; LIMA, R. S. Avaliação de cultivares de mandioca na região noroeste do Paraná. Bragantia, Campinas, v. 59, n. 1, p. 69-75, 2000.

ZADA, M.L.; BECALLI, E.V. 1982. Influencia dela densidad de población em El rendimiento y crescimiento de lãs raíces tuberosas de yuca, Manihot esculenta Crantz. Centro Agrícola. 9, 59-67. 